Prace Literackie LVI

Wrocław 2016

DOI: $10.19195 / 0079-4767.56 .11$

PAWEŁ BERNACKI

Uniwersytet Wrocławski

\title{
Kilka uwag o związku książki artystycznej i literatury pięknej
}

Książka i literatura, a co się z tym wiąże bibliologia i nauki filologiczne, wydają się związane ze sobą nierozerwalnym węzłem. Krzysztof Migoń, pisząc o ich wzajemnych relacjach, podkreślał:

Wcześnie też zaznaczył się w badaniach bibliologicznych nurt filologiczny, tak o orientacji językowej, jak i literackiej, którego ważność wynika z oczywistego skądinąd faktu, że to w książkach utrwalony jest język i literatura i że procesy bibliologiczne (tworzenie, obieg, odbiór książek) współistnieją z językowymi i literackimi ${ }^{1}$.

Trudno dziś sobie wyobrazić funkcjonowanie literatury bez przedmiotu, jakim jest książka. To ona utrwala w sobie dzieło, umożliwia jego odbiór i przechowywanie - niejako zapewnia mu przyszłość. Za jej pośrednictwem efekt pracy pisarza trafia do szerszej publiczności, może być rozpowszechniany, zdobywać sławę czy odciskać swoje piętno na społeczeństwie. Co więcej, przez wieki swojego istnienia, książka — abstrahując od jej formy — okazała się wręcz idealnym medium, pełniącym te funkcje. Powiada Umberto Eco w rozmowie z Jean Claude'em Carrière'em:

Rysuje się tu następująca alternatywa: albo narzędziem lektury pozostanie książka, albo też pojawi się jakiś substytut tego, czym książka była od wieków, nawet przed wynalezieniem druku. Różnorodne formy książki nie zmieniły jej funkcji ani zasadniczych struktur składniowych od ponad pięciuset lat. Odkąd istnieje książka, nie opracowano w zasadzie jej doskonalszej wersji[...] Książka przeszła próbę czasu i trudno sobie wyobrazić, co można by wymyślić lepszego, pełniącego tę samą funkcję. Może zmienią się nieco niektóre jej elementy, może stronice nie będą wykonane z papieru. W sumie jednak pozostanie ona tym, czym jest ${ }^{2}$.

Z powyższych pochlebnych zdań można jednak również wywnioskować, że księga — mimo swojej niezaprzeczalnej ważności i wyjątkowości — pełniła rolę wtórną względem literatury, niejako była jej podporządkowana. Z jednej strony

${ }^{1}$ K. Migoń, Bibliologia [...] nauka o kulturze ksiązki, „Nauka” 2005, nr 2, s. 52.

2 J.C. Carrière, U. Eco, Nie myśl, że książki znikna, przeł. J. Kortas, Warszawa 2010, s. 14-15. 
umożliwiała jej trwanie, z drugiej nie wnosiła doń nic twórczego. Była jedynie owym narzędziem lektury. W powszechnym rozumieniu książka stała się nośnikiem tekstu, a jej artystyczne walory zostały ograniczone do podkreślania jego wartości. Stopiła się ze słowem pisanym, w pewnym sensie utraciła część swojej podmiotowości jako wyjątkowego i autonomicznego przedmiotu. Często przecież, mówiąc o niej, mamy na myśli nie tyle zszyty blok kartek, ile konkretną lekturę. Nawet ruchy związane z piękną książką, które - owszem — postrzegały ją jako dzieło sztuki, widziały w niej raczej kunsztowne, doskonale wykonane opakowanie, szatę dla słowa pisanego. Jak możemy przeczytać w pracach słynnego introligatora Bonawentury Lenarta:

Na tych zasadach oby powstała piękna książka: zespół papieru, czcionek, ozdób, ilustracji, druku i oprawy, mająca na celu połączenie elementów myślowych z elementami materialnemi w zgodną całość - w dzieło pracy — zespalającej wysiłek materialny z duchowym. Oby pragnienie odrodzenia sztuk i rękodzieł znalazło wyraz jednolity, mimo różnorodności założeń — służąc jedynemu celowi - pięknu życia ${ }^{3}$.

Wtórował mu na łamach „Polskiej Gazety Introligatorskiej” inny przedstawiciel tego rzemiosła Władysław Grabowski:

Wykonawca znaleźć musi pewną harmonię z całością — harmonię kolorów i formy. Mistrz sztuki krawieckiej ubiera swoją klientkę odpowiednio do jej charakteru i jej sytuacji społecznej słowem, by piękna pani czuła się w tem dobrze. Introligator, projektując okładkę książki, powinien wypowiedzieć się w takiej koncepcji dekoracyjnej, któraby całkowicie odpowiadała powadze autora, treści dzieła, formie typograficznej i założeniom projektowanej techniki, czyli, że sztuka oprawy książki jest sztuką współpracy — podobną do sztuki akompaniamentu fortepianu do śpiewu solisty ${ }^{4}$.

Chodziło więc o uchwycenie harmonii, dopasowanie kodeksu do dzieła, które będzie na nim zapisane. Gdyby zastosować terminologię użytą w drugim z cytowanych fragmentów, literatura byłaby klientką krawca, książka zaś uszytą dla niej suknią, która podkreśli walory ciała i charakteru kupującej oraz w której ta będzie się dobrze czuła. Księga jest dopasowywana do tekstu, ma stworzyć z nim harmonijną całość, być mu podporządkowana. Jawi się jako przedmiot piękny, ale nie - przynajmniej nie do końca — autonomiczny. Podsumowując powyższe — zawierające pewne uproszczenia zdania — można stwierdzić, że w związku literatury i książki dominującą rolę pełni ta pierwsza. W ogólnej świadomości słowo pisane zdaje się organizować całość tego, co moglibyśmy nazwać dziełem książkowym, a tekst i nośnik, na którym go zapisano, to niemal jedno.

Sytuacja ta zaczęła się zmieniać wraz z pojawieniem się na przełomie XIX i XX wieku różnego rodzaju awangardowych ruchów, takich jak futuryzm czy dadaizm. Pośród swoich licznych postulatów ich przedstawiciele domagali się także uwolnienia słów z okalających je ograniczeń, zwrócenia uwagi na dźwiękowe

3 B. Lenart, Piękna ksiązka: zespót papieru, czcionek, ilustracyi, druku i oprawy, Wilno 1928 , s. 18.

${ }^{4}$ W. Grabowski, Sztuka oprawy książki a sztuka toalety, „Polska Gazeta Introligatorska” 4 , 1931, nr 5, s. 66. 
i fizyczne aspekty tekstu. Zależało im na oderwaniu go od języka i związanych z nim konwencji. W słynnym manifeście Prymitywiści do narodów świata i Polski można między innymi przeczytać:

poezja. Pozostawiamy rym i rytm, gdyż są pierwsze i zapładniające. zniszczenie zacieśniających twórczość reguł zaleta niezgrabności. dowolność form gramatycznych, ortografii i przestankowania, w zależności od twórcy [...]. SŁOWA mają swą wagę, dźwięk, barwę, swój rysunek, ZAJMUJĄ MIEJSCE W PRZESTRZENI, są to decydujące wartości słowa, słowa najkrótsze (dźwięk) i słowa najdłuższe (książka), znaczenie słowa jest rzeczą podrzędną i nie zależy od przypisywanego mu pojęcia należy je traktować jako materiał dźwiękowy UŻYTY NIEONOMATOPEICZNIE ${ }^{5}$

oraz:

główne wartości książki — to format i druk jej, po nich dopiero — treść, dlatego poeta powinien być zaraz zecerem i introligatorem swej książki, powinien sam ją wszędzie krzyczeć, nie deklamować. do rozpowszechnienia użyć gramofonu i kina, gazety, gramofony rozjeżdżające, płótno ekranu lub ściana, jako karta zbiorowo odczytywanej książki $[\ldots]^{6}$.

W przytoczonych fragmentach wyraźnie podkreślone zostają graficzne aspekty słowa: jego waga, dźwięk, barwa, rysunek, fakt, że zajmuje miejsce w przestrzeni. Co jednak istotniejsze z punktu widzenia tego tekstu, postulaty te zostają następnie przeniesione na książkę, jako „najdłuższy z wyrazów”. Za jej podstawowe wartości uznane zostają format i druk. Treść znajduje się na dalszym planie. Co więcej, od poety wymaga się, by był jednocześnie zecerem i drukarzem, a więc wziął odpowiedzialność również za wygląd swojej publikacji.

Te oryginalne w swoim czasie postulaty znalazły odbicie w późniejszych, powojennych ruchach związanych z poezją fonetyczną, wizualną i konkretną. Jak zaś słusznie zauważa Piotr Rypson: ,wiersz konkretny przekształcał tekst w obiekt: stąd już bliska droga do książki-obiektu"7. Takie — konceptualne myślenie położyło podwaliny pod ukucie w latach sześćdziesiątych XX wieku pojęcia książki artystycznej. Tym — bardzo rozległym, elastycznym i ciągle nie w pełni zdefiniowanym - terminem określa się szereg prądów odważnie eksperymentujących z ideą i formą księgi. Charakteryzuje je postrzeganie książki jako wyjątkowego i, przede wszystkim, autonomicznego przedmiotu oraz próby przywrócenia jej podmiotowości. Patrzenie na nią jak na dzieło sztuki samo w sobie. Niestety owe bardzo ogólne wyznaczniki nie pozwalają na klarowne opisanie i wydzielenie ram tego zjawiska. Przy spojrzeniu na próby uchwycenia jego istoty często natrafia się na zdania o charakterze ogólnym, jak to autorstwa

5 A. Wat, A. Stern, Prymitywiści do narodów świata i Polski, [w:] Antologia futuryzmu polskiego i nowej sztuki, red. Z. Jarosiński, Wrocław 1978, s. 5.

6 Ibidem, s. 6.

7 P. Rypson, Ksiązki i strony. Polska ksiązka awangardowa i artystyczna w XX wieku, Warszawa 2000, s. 92. 
Dicka Higginsa, twierdzącego iż jest to „książka robiona dla niej samej, nie zaś dla informacji, którą zawiera"8 . Równie szeroki wydźwięk ma najpopularniejsza z rodzimych definicji artist's book autorstwa Piotra Rypsona:

Książka artystyczna, dzieło autonomiczne - powstaje jako samodzielna praca artystyczna (np. książki W. Kamieńskiego, F. Depero, prace M. Szczuki) lub przy ścisłej współpracy artysty i literata - np. Dla Gołosa Majakowskiego - Lissickiego, Europa Szczuki - Sterna, Z ponad Przybosia - Strzemińskiego. Najogólniej rzecz ujmując, artystyczne prace książkowe miały przełamywać podział na tekst (rozwijający się w czasie) i grafikę (oglądaną w przestrzeni) ${ }^{9}$.

Rodząca kłopoty terminologiczne rozległość i pewna niedookreśloność opisywanego zagadnienia sprawia, że w jego ramy wpisuje się wiele często różnych od siebie prądów. Na gruncie polskim do najważniejszych z nich należą piękne książki, liberatura i book objects. W przypadku pierwszego z nich mamy do czynienia z pracami, które poza nielicznymi wyjątkami zachowują formę kodeksu. Tym, co wyróżnia je na tle pozostałych publikacji, jest wysoka jakość materiałów, z jakich zostały stworzone, kunsztowne wykonanie i przede wszystkim próba osiągnięcia harmonii między wszystkimi elementami dzieła, zarówno duchowymi (treść), jak fizycznymi (odpowiedni dobór papieru, czcionki, kompozycja strony, projekt okładziny i inne). Projekty liberackie są bardziej eksperymentalne. Ruch ten akceptuje nawet bardzo oryginalne formy książek - jak, na przykład Spogladając przez Ozonowa Dziurę Zenona Fajfera wydaną jako szklaną butelkę z listem w środku — pod warunkiem, że służą one podkreśleniu literackich walorów dzieła. Tekst jest tutaj czynnikiem dominującym, organizującym całość publikacji. To jemu są podporządkowane jej pozostałe elementy. Book objects to $\mathrm{z}$ kolei projekty sytuujące się raczej w ramach sztuk wizualnych. Bliżej im do rzeźb i instalacji artystycznych niż kodeksów. Tekst stanowi tylko jeden z ich składników, a jego rola bywa często marginalizowana. Projekty te nawiązują do księgi na poziomie idei i świadomie konfrontują się z narosłą wokół niej tradycją. Mamy tu do czynienia z pracami na wskroś eklektycznymi, czerpiącymi z wielu różnych źródeł i przełamującymi formalne granice. Są miejscami spotkania różnych sztuk: literatury, plastyki, rzeźby, krawiectwa, muzyki i innych. Ze względu na te aspekty będą one szczególnie interesujące z punktu widzenia niniejszego tekstu.

Wśród book objects dużą grupę stanowią prace będące nawiązaniem do dzieł literackich, ich interpretacją. Mamy do czynienia z książką, która nie tyle jest nośnikiem tekstu, ile jego twórczym przetworzeniem. Urasta do rangi autonomicznej, artystycznej wypowiedzi, która zamiast przenosić i utrwalać słowo pisane dąży do konfrontacji z nim. Za pomocą właściwych sobie środków podejmuje intertekstu-

8 Podaję za: T. Wilmański, Książka jako zjawisko artystyczne, [w:] Książka artystyczna jako obiekt oraz warsztat edukacyjny, Zielona Góra 1998, s. 16.

9 P. Rypson, op. cit., s. 11. 
alny dialog z daną powieścią, wierszem czy dramatem. Dzieło literackie staje się dla artysty punktem wyjścia, impulsem pobudzającym go do twórczego działania. Czymś, co Roland Barthes określiłby jako punctum.

W swoim świetnym eseju o fotografii pt. Światło obrazu francuski badacz zastanawiał się, co sprawia, że niektóre zdjęcia oddziałują na niego mocniej od innych. Dlaczego jedne wzbudzają w nim silne emocje, zapadają w pamięć, a obok drugich przechodzi zupełnie obojętnie i często po krótkim czasie zapomina, że w ogóle je widział. W toku swoich rozważań Barthes dochodzi do dwóch pojęć, które w jego opinii mają wpływ na odbiór fotografii: studium i punctum:

Pierwszy to niewątpliwie obszar, całe pole, które postrzegam jako coś bliskiego, gdyż związane jest z moją wiedzą, kulturą ogólną. To pole może być mniej czy bardziej stylizowane, mniej czy bardziej udane, zależne od sztuki czy szansy fotografa. Odsyła jednak zawsze do podstawowej informacji (rewolta, Nikaragua) i wszystkich znaków do tego należących: biedni, nieumundurowani insurekcjoniści, zrujnowane ulice, trupy, ból, słońce i ciężkie indiańskie powieki. Zrobiono na tym obszarze tysiące zdjęć i mogę oczywiście odczuwać zainteresowanie nimi, czasem przejęcie, ale te emocje przychodzą do mnie za rozumowym pośrednictwem mojej kultury moralnej i politycznej. To, co odczuwam wobec tych zdjęć, pochodzi z uczuć średnich, prawie z tresury.

\section{I dalej:}

Nie znajdowałem w języku francuskim słowa, które wyrażałoby po prostu ten rodzaj ludzkiego zainteresowania; jednak słowo takie istnieje, jak sądzę, w łacinie: to słowo studium, które nie narzuca jeszcze, przynajmniej nie od razu, pojęcia „studium [malarskiego]”, ale jakąś dociekliwość, oddanie się pewnej rzeczy, skłonność do kogoś, pewien rodzaj ogólnego wciągnięcia się w coś, krzątaninę, oczywiście, ale bez szczególnego zapamiętania. To za pośrednictwem studium interesuję się wieloma zdjęciami, bądź odbierając je jako świadectwa polityczne, bądź smakując jak dobre obrazy historyczne. Gdyż to właśnie poprzez kulturę (to znaczenie jest także obecne w studium) uczestniczę w wyrazie twarzy, gestach, realiach, działaniach ${ }^{10}$.

Studium zatem to powszechnie dostępna wiedza. Pewien rodzaj ogólnej wrażliwości, który został w nas zakorzeniony w procesie socjalizacji. Znajduje się na poziomie, do którego dostęp ma niemal każdy. To dzięki niemu jesteśmy w stanie ulokować sfotografowaną scenę w danym miejscu i czasie, ocenić ją wedle przyjętych przez społeczność kryteriów. Ono także wywołuje w nas określone — by nie rzec zaprogramowane - uczucia: litość dla cierpiących, strach przed wojną, pogardę wobec katów i tak dalej. Tym właśnie jest studium: wypracowanymi wzorcami zachowań. To wiedza książkowa połączona z uznanymi przez grupę możliwościami reakcji na dane sytuacje. Z jednej strony narzuca nam pewne ramy, ogranicza nas, z drugiej pomaga odnaleźć się w zbiorowości, współżyć i kooperować z nią.

W opozycji do studium Barthes stawia punctum — rozrywający je, indywidualny czynnik:

10 Ten i poprzedni cytat za: R. Barthes, Światło obrazu, przeł. J. Trznadel, Warszawa 2008, s. $49-51$. 
Drugi element przełamuje studium lub poddaje je rytmowi. Tym razem to nie ja go szukam (ponieważ moja świadomość zajmuje się polem studium), to on wybiega ze sceny jak strzała i przeszywa mnie. Po łacinie znów istnieje słowo dla wyrażenia tej rany, tego użądlenia, tego znaku uczynionego przez zaostrzony przedmiot. To słowo odpowiadałoby mi tym bardziej że odsyła także do znaku kropki, a zdjęcia są rzeczywiście jakby zaznaczone punktami, czasem nawet usiane tymi wrażliwymi miejscami. Bo właśnie te znamiona, te rany są punktami. Dlatego ten drugi element, który narusza studium, nazwę punctum; albowiem punctum to także użądlenie, dziurka, plamka, małe przecięcie - ale również rzut kośćmi. Punctum jakiegoś zdjęcia to przypadek, który w tym zdjęciu celuje we mnie [me point] (ale też uderza mnie, miażdży) ${ }^{11}$.

Punctum jest tym, co w nas na wskroś indywidualne. Wypływa z doświadczeń jednostki. To element podświadomy „bardzo trudny do racjonalnego wyjaśnienia. Swoje źródło ma prawdopodobnie gdzieś w naszej przeszłości, w głębokich, osobistych przeżyciach. Nie mieści się w społecznych ramach i nie jest efektem procesu socjalizacji. Przeciwnie - tworzy w nim wyrwę. Dla każdego z nas będzie czymś innym, niepowtarzalnym i niedostępnym dla nikogo poza nami. To jakaś tkwiąca głęboko w nas zadra. Rana, która otwiera się na skutek impulsu wywołanego fotografią. O ile więc studium stanowić będzie pewien zbiór dostępnych dla wszystkich kompetencji niezbędny do osadzenia zdjęcia lub szerzej — dzieła sztuki — w określonych realiach, oswojenia go i poznania według ogólnie przyjętych reguł, o tyle punctum zaistnieje tylko dla nielicznych. Co więcej, w każdym indywidualnym przypadku będzie inne. To element oddziałujący na konkretną osobę, który ujawni się w jednym spośród setek dzieł. Tym, które w jakiś sposób przyciągnie do siebie odbiorcę, „zrani go”. Według Barthes'a znajduje się ono w porządku to love, podczas gdy studium tylko w to like. Jedno jest zaledwie niezłe i lubiane, drugie to silne przeżycie, wobec którego nie da się przejść obojętnie.

Rozważania te można przenieść na grunt książki artystycznej. Księga — pisana wielką literą, rozumiana jako pewna idea — wraz z całą narosłą wokół niej tradycją stanowiłaby tutaj przestrzeń studium. Jej forma i funkcja są powszechnie przyjęte i akceptowalne. Niezależnie czy będzie to zwój, kodeks czy e-book u swojego źródła będzie to zawsze przedmiot do czytania, mający na celu utrwalanie i przenoszenie treści. Dodatkowo w powszechnej świadomości będzie on $\mathrm{w}$ zasadzie stopiony $\mathrm{z}$ tekstem, złączony z nierozerwalnym węzłem z dziełem literackim. Książka artystyczna ów związek rozbija. Stanowi punctum - skazę, od której utrwalony od wieków porządek zaczyna pękać. Za jej sprawą księga odzyskuje swoją podmiotowość i autonomię. Jej związki z literaturą są nadal oczywiste i niezaprzeczalne, jednak sam charakter tej relacji ulega zmianie. Tekst przestaje być widziany jako nieodzowny i dominujący składnik książki. Okazuje się, że przedmiot dotychczas postrzegany jako nośnik treści może stanowić już interpretację, a nawet niezależne od niej dzieło sztuki, funkcjonujące na takich samych zasadach.

11 Ibidem, s. 51-52. 
Tego typu samodzielnych projektów książkowych znajdziemy naprawdę wiele. W licznych przypadkach stanowią one artystyczną wariację na temat tekstów literackich. W tym miejscu uwidacznia się oddziaływanie relacji studiumpunctum na innym poziomie. Każdy czytelnik posiada kompetencje niezbędne do przynajmniej podstawowego umiejscowienia lektur w szerszym kontekście historycznym, społecznym czy geograficznym, co umożliwia mu ich zrozumienie i późniejszą interpretację. Nie będzie dużym nadużyciem stwierdzenie, że wszyscy, którzy opanowali umiejętność czytania są w stanie pojąć zadany tekst na pewnym bazowym poziomie i wyciągnąć z niego podobne, rudymentarne wnioski. Jednocześnie jednak dzieło literackie oddziałuje również indywidualnie, może stanowić dla kogoś punctum. „Uderza” ono odbiorców, wśród nich artystów. Jest impulsem do podjęcia dalszej, twórczej pracy. Za jego sprawą pojawiają się próby nowatorskich interpretacji najróżniejszych tytułów i przenoszenia uwagi na ich pomijane dotąd aspekty. Podejmowane są starania o wyrwanie tekstów literackich $\mathrm{z}$ utartych kolein i zaprezentowanie ich pod innym kątem, w nieznanym jeszcze świetle. Efektami takich wysiłków jest duża grupa artist's book, stanowiących ożywcze odczytania poetyckich i prozatorskich dzieł. Wskazane będzie poświęcenie uwagi jej konkretnym przykładom.

Wydaje się, że można wyróżnić dwa rodzaje tego typu zależności: sytuację, gdy książka stanowi interpretację tekstu literackiego oraz kiedy jest ona osobnym artystycznym projektem jedynie nim zainspirowanym ${ }^{12}$. Doskonałym przykładem pierwszej z nich jest praca Renaty Pacyny-Kruszyńskiej Ten, który spada, która otrzymała pierwszą nagrodę podczas ósmej edycji Międzynarodowego Festiwalu Sztuki Książki pt. „Czas”. Dzieło jest adaptacją opowiadania Sławomira Mrożka pod tym samym tytułem ${ }^{13}$. Filozoficzna nowelka słynnego dramaturga opowiada o człowieku lecącym w dół. Podczas swojej drogi spotyka on najróżniejsze postacie. Niektóre po prostu mija, z innymi wdaje się w różnego rodzaju interakcje. Zauważa zarówno postaci spadające obojętnie, bez żadnych emocji, jak i takie, które nie akceptując swojego losu, próbują walczyć: biją rękoma na oślep, szukają punktów zaczepienia, robią wszystko, by jakoś opóźnić swój upadek. Uwagę bohatera w szczególności przyciąga jednak wielka, uformowana z ludzi kula, do której w pewnym momencie się zbliża:

Przyzwyczajony, że spada się pojedynczo, nie od razu zrozumiałem, że ta ciemna, bura masa składała się z ludzi. Też spadali, ale jak spadali! Tworzyli zwartą kulę o średnicy chyba kilometra i byli sczepieni ze sobą w ten sposób, że żaden z nich nie zwracał się twarzą na zewnątrz, lecz do

12 Osobną grupę stanowią prace książkowe, których forma została zaplanowana przez pisarza i stanowi integralny składnik napisanego przez niego nowego dzieła. Ze względu jednak na fakt, że nie są one twórczym przetworzeniem znanego wcześniej tekstu literackiego, lecz inherentną częścią utworu, zostały one wyłączone poza obręb zainteresowania niniejszego artykułu. Do grupy tej możemy zaliczyć na przykład publikacje z serii Liberatura oraz prace wszechstronnego artysty Radosława Nowakowskiego.

13 S. Mrożek, Ten, który spada, [w:] idem, Opowiadania 1974-1979, Warszawa 1999, s. $293-$ 301. 
środka. Nie widać więc było żadnej twarzy, same tylko wypięte tyły i grzbiety. Whaczeni w siebie nawzajem, wprasowani i wbici jeden w drugiego, tworzyli wspólnie stwór jednolity, o regularnym kształcie, kuli właśnie. Rodzaj małej planety. Kula wydzielała silny odór ${ }^{14}$.

Ten opis stał się inspiracją dla tworzącej książkę artystki. Jej dzieło to liczący sobie siedem stron, wykonany z przeźroczystego szkła kodeks o wymiarach trzydzieści na czterdzieści centymetrów. Zapisane na nim opowiadanie Mrożka uformowano w kształt koła, które po zamknięciu książki zmienia się w czarną, nieczytelną figurę geometryczną przypominającą walec. Jedynie znajdujące się na pierwszej karcie informacje o autorze i tytule tekstu są od niej oddzielone. Jak mówiła sama autorka: „Nazwisko autora i tytuł zostały tu wykorzystane jako element kontrastowy do kuli. Kruchy odcinek tekstu mający lada moment ulec destrukcji poprzez zderzenie z tekstem opowiadania"15. Forma książki to niejako zilustrowanie opowiadania zarówno w sensie metaforycznym, jak i dosłownym. Położenie spadającego zostało tu ukazane bardzo plastycznie. Symbolizujące go informacje z personaliami autora zmierzają w kierunku wielkiej, czarnej kuli. Niebawem dojdzie do zderzenia. W jego następstwie narrator zatraci swoją osobowość i indywidualność, stopi się z czarną masą tekstu. Dodatkowo sposób zapisu noweli - po zamknięciu kodeksu tworzący pionowy walec bądź lej — może symbolizować przestrzeń, w której znajduje się bohater i jednocześnie oddawać jego sytuacje. Trzeba mieć na uwadze, że spada on z góry na dół, a nie z jednej strony na drugą. Kolejne widziane przez niego obrazy, fragmenty tekstu nakładają się na siebie, rozmazują się i stają nieczytelne. Taki wygląd książki jest bliższy perspektywie narratora i jednocześnie sprawia, że jego sytuacja jest bardzo plastycznie zobrazowana odbiorcy - typografia i rozplanowanie przestrzenne strony niejako ilustrują fabułę noweli.

Warto również zwrócić uwagę na fakt, że słowami, które zmierzają w kierunku stworzonej ze słów kuli, są dane autora i tytuł jego opowiadania. Tak, jakby w tym spojrzeniu Sławomir Mrożek był tym, który spada. Być może w ten sposób Pacyna-Kruszyńska chciała nawiązać do metaforycznej śmierci autora, który „ginie” we własnym tekście, pokazać, jak twórczość zawłaszcza i jednocześnie kreuje obraz pisarza. Dzieło jest przecież tym, co zostaje po twórcy. To dzięki niemu, ale równocześnie $\mathrm{w}$ nim przechowywana jest pamięć o twórcy. Tym samym za sprawą zastosowania oryginalnej formy artystce udało się zarówno zilustrować treść opowiadania, jak i wysnuć ogólną refleksję na tematy związane ze sztuką. Jeśli zaś spojrzeć na hasło przewodnie całego festiwalu, na którym omawiana praca została zaprezentowana, a więc „czas”, będzie się ona jawić jako metafora ludzkiej egzystencji i przemijania, co jeszcze bardziej zbliży ją do opowiadania Mrożka.

14 Ibidem, s. 298.

15 R. Pacyna-Kruszyńska, Ten który spada, http://2006.bookart.pl/index.php?module=Pagese tter\&func $=$ viewpub\&tid=2\&pid=103 [dostęp: 31.08 .2016$]$. 
Inną książką artystyczną odwołującą się do motywu przemijania jest niosący ze sobą bardzo silny ładunek emocjonalny Orfeusz i Eurydyka autorstwa Jadwigi i Janusza Tryznów. Ten nietypowy projekt ma kształt wysokiego, metrowego piedestału, na którym umieszczona została rozwarta księga. Na jej opadających, niesymetrycznie długich stronach widnieje niemiecki przekład poematu Czesława Miłosza nawiązujący do słynnego mitu. W grzbiecie woluminu dodatkowo ukryto płyty DVD zawierające najróżniejsze, literackie odwołania do starogreckiej legendy. Całość kompozycji przypomina swoim wyglądem wierzbę płaczącą, co raczej nie jest przypadkiem. Wskazuje na to wypisana na słupie podtrzymującym księgę historia powstania publikacji, której ostatni epizod wspomina Jadwiga Tryzno:

Ostateczny kształt książka uzyskała po okresie czasu codziennego lania na jej karty wody przez artystę trwającego w żałobie po śmierci żony. Pedro Warnke w ten sposób wypełnił „treścią" podarowaną mu, celowo niedokończoną formę książki ${ }^{16}$.

Wywołany stratą ukochanej ból mitycznego pieśniarza zostaje zestawiony $\mathrm{z}$ analogicznym cierpieniem, jakie dotknęło współczesnego polskiego poetę Czesława Miłosza ${ }^{17}$ i niemieckiego artystę Pedra Warnkego. Publikacja Tryznów próbuje pokazać, że pomimo upływu tysięcy lat i związanych z tym przemian kulturowych, społecznych i cywilizacyjnych rozpacz po śmierci najbliższej osoby jest odczuwana w taki sam sposób i z równie dużą siłą. Jest to ogromny ból, który musi znaleźć gdzieś ujście. W tym miejscu sygnalizowana jest terapeutyczna funkcja sztuki, ale również omawianego dzieła. Jak wiemy z mitu, po śmierci Eurydyki Orfeusz aż do swego tragicznego końca śpiewał sławiące ją pieśni żałobne. Polski noblista szukał ukojenia w napisaniu poematu. Projekt małżeństwa Tryznów miał z kolei przynieść pocieszenie Warnkemu. W jego gestii leżało nadanie książce ostatecznego kształtu. Artysta uznał, że cel ten osiągnie przez codzienne polewanie go wodą symbolizującą zapewne łzy. Cykliczność tej czynności, dająca stopniowy upust emocjom, miała z czasem przynieść mu spokój lub przynajmniej zmniejszyć jego cierpienie.

Projekt Orfeusz i Eurydyka, przełamując granice między literacką fikcją a rzeczywistością, pokazuje, że ból po stracie bliskiej osoby jest uczuciem uniwersalnym i ponadczasowym. Doświadczają go legendarni bohaterowie i śmiertelnicy. Tak samo cierpi przecież mityczny heros i współczesny artysta. Jednocześnie książka artystyczna Tryznów wskazuje na to, jakie ukojenie może przynieść sztuka i jak ważna jest jej rola w życiu. Nie tylko gromadzi i interpretuje najróżniejsze historie o trackim pieśniarzu i jego żonie, lecz także dopisuje do nich kolejny rozdział. Ze względu na swój niezwykle silny ładunek emocjonalny publikacja ta

16 J. Tryzno, Czas ksiązki, http://2006.bookart.pl/index.php?module=Pagesetter\&func=viewp ub\&tid=4\&pid=0\&page $=3$ [dostęp: 2.09 .2016$]$.

17 Utwór Orfeusz i Eurydyka został napisany przez Czesława Miłosza po śmierci jego drugiej żony Carol Thigpen-Miłosz. 
wykracza daleko poza granice nośnika tekstu i urasta do rangi autonomicznego dzieła sztuki, które - owszem - przechowuje tekst literacki, ale jednocześnie w bardzo dużym stopniu wzbogaca jego przesłanie.

Jeszcze dalej w formalnym nowatorstwie posuwa się inna publikacja wspomnianej wcześniej Renaty Pacyny-Kruszyńskiej Heloiza. Ubrana, odstonięta. Projekt ten — odwołujący do listów średniowiecznych kochanków: Abelarda i Heloizy — możemy już uznać za artist's book jedynie inspirowaną literaturą. Praca ta nie tyle interpretuje tekst, ile jest stworzonym na jego bazie zupełnie nowym dziełem. Omawiana książka artystyczna posiada bowiem formę białej, długiej sukni z lnu o zbyt długich rękawach i przymocowanych na plecach trokach. $\mathrm{Z}$ jednej strony jest skromna niczym zakonny habit, $\mathrm{z}$ drugiej za sprawą swoich dodatków przywołuje skojarzenia $\mathrm{z}$ kaftanem bezpieczeństwa. Jest to ewidentne nawiązanie do łączącego kochanków uczucia. Ich miłość była szczera i prosta, ale jednocześnie zakazana. Zawierała w sobie silny pierwiastek szaleństwa, który mocno ją napiętnował. Dodatkowo przytwierdzone do pleców troki wraz z długimi rękawami mogą symbolizować realia społeczne i historyczne, które od samego początku krępowały ów związek i ostatecznie sprawiły, że Abelard i Heloiza dożyli swoich dni osobno.

Tym jednak, co najistotniejsze w projekcie Pacyny-Kruszyńskiej, jest treść trzech listów: Abelarda Do przyjaciót i napisanych w jego następstwie dwóch pism Heloizy. Znajdują się one na zasłoniętych zewnętrzną warstwą sukni długich, płóciennych płachtach, które ciągną się od okolic biustu aż do stóp. Stają się one widoczne dopiero, gdy czytelnik odsłoni pokrywające je poły stroju. Taka forma zapisu tekstu jest czytelnym nawiązaniem do ciąży, która była owocem miłości kochanków. Wraz z rozwojem płodu rosnący brzuch kobiety będzie wypychał treść listów na zewnątrz, a tajemnica zakochanych zostanie odsłonięta przed światem. Heloiza jest więc jednocześnie ubrana — nosi suknie — i odsłonięta: za sprawą praw natury jej sekret niebawem zostanie odkryty.

Mamy tu do czynienia z książką artystyczną, która stanowi pewien proces. Można założyć, że w intencji artystki idealną modelką do założenia tej sukni była kobieta w stanie błogosławionym, której zmieniające się ciało, stopniowo wypychałoby tekst na zewnątrz. Wydaje się, że nie jest przypadkiem na części wystaw analizowany strój był prezentowany nie na wieszaku czy manekinie, lecz żywej osobie. Nadawało to dziełu autentyzmu, wskazywało, że historia Abelarda i Heloizy nie jest fikcją, lecz wydarzyła się naprawdę.

Innym niezwykle interesującym przykładem książki artystycznej inspirowanej dziełem literackim są Dwie odstony pamiętnika Magdaleny Haras. Praca nawiązuje do dziennika Sławomira Rawicza Dlugi marsz, wydanego pierwotnie 1955 roku w Wielkiej Brytanii pod tytułem The long walk. Przedstawia on obecnie kwestionowaną - historię autora, który po kampanii wrześniowej trafił do sowieckiej niewoli i został skazany na dwadzieścia pięć lat ciężkich robót na Syberii. Wraz z grupą współwięźniów udało mu się zbiec z obozu pracy i po po- 
konaniu sześciu tysięcy kilometrów dostać się do Indii. W celu zobrazowania trudu tej morderczej wędrówki Haras nadała swojemu dziełu formę pary zniszczonych, niebieskich trzewików. Na kolejnych warstwach ich rozklejających się podeszew artystka zapisała fragmenty pamiętnika Rawicza: na prawym bucie w języku angielskim, a na lewym w polskim. Tym samym autorka zwróciła uwagę na problemy, jakie przeszedł dziennik, który z powodów politycznych przez kilkadziesiąt lat nie mógł być wydany w ojczyźnie pisarza. Napisany odręcznym pismem tekst wzmaga intymność pracy Haras oraz podkreśla pamiętnikarski charakter jej pierwowzoru. Nadanie dziełu formy obuwia jest zaś oczywistym odniesieniem do ogromnego, tytanicznego trudu związanego z wędrówką przez Azję. Jak wspomina artystka:

Założeniem artystycznym jest przedstawienie idei marszu, drogi, przejścia nie tylko przez bezkresne przestrzenie, ale także przez najgorsze, bo zadane przez drugiego człowieka cierpienia, fizyczne i psychiczne. Ten symboliczny kształt — but — tutaj przywodzi na myśl niezwykły hart ducha bohaterów, ich wolę osiągnięcia celu: wolności. Także wolności słowa ${ }^{18}$.

Pomysł, jaki przyświecał Haras, jest znacznie ambitniejszy niż artystyczne zobrazowanie treści książki Rawicza. Autorce chodziło o dotknięcie wielowymiarowego sensu wędrówki. Skupienie się na idei szeroko pojmowanej drogi. Może być ona rozumiana dosłownie jako maszerowanie, piesze pokonywanie setek kilometrów, ale także metaforycznie jako podróż wewnętrzna, zmaganie się z własnymi słabościami, przechodzenie przez piekło obozu pracy, próba wyzwolenia się z wewnętrznych i zewnętrznych kajdan. Wreszcie warto też pamiętać o swoistej „wędrówce”, jaką przeszedł tekst Rawicza, nim mógł w końcu zostać opublikowany w Polsce. Dwie odstony pamiętnika rozszerzają problematykę Dlugiego marszu. Wychodząc od jej literalnego sensu, dobudowują wokół niej kolejne konteksty i znaczenia. Dziennik Rawicza opisujący fizyczną ucieczkę przez azjatyckie bezdroża staje się impulsem do wysnucia refleksji na temat drogi, jaką trzeba przebyć, by znów poczuć się wolnym. Słowo pisane jest tutaj punktem wyjścia, lecz samo przesłanie książki artystycznej sięga już daleko poza nie.

Zarówno praca Małgorzaty Haras, jak i Heloiza Renaty Pacyny-Kruszyńskiej podchodzą wieloaspektowo do tekstów, na których się opierają. Traktują je jako zaproszenie do dalszej twórczej wędrówki. W przeciwieństwie do omawianych wcześniej Tego, który spada oraz Orfeusza i Eurydyki nie tyle obrazują utwory, do których nawiązują, ile odbijają się od nich i próbują sięgnąć gdzieś dalej. Na dobre porzucają też formę kodeksu, szukając innych środków wyrazu. Ich związki z literaturą są niezaprzeczalne, ale stosunkowo luźne. Są czymś na wzór artystycznego odpowiednika współczesnej ekfrazy, gdy to tekst jest „opisywany” przez dzieło

${ }_{18}$ M. Haras, Dwie odsłony pamiętnika, http://korespondencja.bookart.pl/ksiazki/dwie_odslony_pamietnika.html [dostęp: 1.09.2016]. 
sztuki. Obrazują go, odnoszą się do niego, a jednocześnie snują na jego bazie zupełnie nową narrację. Utwór literacki zmienia swoją rolę i staje się kontekstem interpretacyjnym dla innej, niezależnej od niego wypowiedzi artystycznej.

Wszystkie przytoczone przykłady stanowią impuls do postawienia pytań o to, czym jest i czym może być książka oraz ponowne przemyślenie jej związków z literaturą. Wyraźnie widoczna w ostatnich latach technicyzacja życia i związana z nią ekspansja e-booków w jeszcze większym stopniu rozluźnia te relacje. Za ich sprawą tekst stopniowo traci swą materialną postać i przenosi się do cyberprzestrzeni. Z dużą dozą prawdopodobieństwa można stwierdzić, że najpopularniejsza obecnie forma książki — kodeks — będzie wypierana przez swój elektroniczny odpowiednik. Zostanie zastąpiona swoją nowszą wersją, tak jak przed wiekami ona zajęła miejsce zwojów i tabliczek. Te ostatnie jednak bynajmniej nie zniknęły z naszej rzeczywistości. Zmieniła się ich rola. $Z$ przedmiotów codziennego użytku stały się wyjątkowymi, rzadkimi, służącymi na przykład podkreśleniu wzniosłości danej sytuacji czy ważności teksu bądź dokumentu. Być może podobny los spotka wszelką materialną postać książki. W takiej sytuacji jej związki z literaturą mogą ulec jeszcze większemu rozluźnieniu, a ona sama mogłaby przeistoczyć się w zupełnie nową gałąź sztuki.

Są to oczywiście jedynie przypuszczenia, a ich zanegowanie lub potwierdzenie będzie wymagało czasu. Niewątpliwie jednak kolejne przykłady artist's books udowadniają istnienie szerszego od powszechnego myślenia o książce. Patrzenia na nią jak na dzieło sztuki samo w sobie i odrywania jej od literatury, z którą do tej pory wydawała się ściśle związana. Jest to spojrzenie oryginalne i nowatorskie. Wzbudza wiele kontrowersji. Stosunkowo często pojawią się krytyczne opinie na jego temat, twierdzące, że — przynajmniej w wypadku book objects — w ogóle nie powinniśmy mówić o książce. Zgadzając się z tą opinią, należałoby jednak zaakceptować powstanie nowej, wyrosłej na kanwie livre d'art, dziedziny sztuki, dla której konieczne byłoby stworzenie odpowiedniej nazwy, wytyczenie jej granic etc. Są to już jednak rozważania wykraczające daleko poza zasadniczą tematykę niniejszego artykułu.

Przytoczone tu artystyczne projekty wpisujące się w obręb artist's books są przykładami tego, jak rozbudowane i skomplikowane mogą być wzajemne relacje między dziełem książkowym a literackim. Pierwsze nie musi być wcale podległe drugiemu. Wręcz przeciwnie - samo może nie tylko ilustrować i wzbogacać tekst pisarski, lecz także budować na jego bazie niezależną, interesującą i oryginalną wypowiedź. Trudno dziś jednoznacznie określić, w jakim kierunku podążą twórcy książek artystycznych i jak będą wyglądały dalsze losy tej dziedziny twórczej aktywności. Już dziś jednak za jej dużą zasługę możemy uznać ożywcze tchnienie, jakie wnosi ono w dosyć skostniały układ łączący teksty z ich nośnikami. Wydaje się, że to powiew, który przyniesie wiele ciekawych rozwiązań i dla sztuki, i - 
być może - literatury, a dodatkowo ma szansę stać się wdzięcznym przedmiotem humanistycznych analiz. Choćby wyłącznie z tego względu należało poświęcić mu odrobinę czasu i uwagi.

\title{
Some remarks on the link between artists' books and belles-lettres
}

\begin{abstract}
Summary
The book art and literature seem to be closely linked. Almost from the very beginning of its existence the former was used to store, disseminate and highlight the values of the latter. This state of affairs began to change at the turn of the 20th century, when the great avant-gardes were increasingly emphasising the visual aspects of the written word and, consequently, of books. People were increasingly convinced about the autonomy and independence of books. This led to the emergence in the 1960s of a movement known as artists' books, which considered books to be works of art in themselves, and consequently, to be more loosely connected with literature. This broad and not yet fully defined phenomenon encompasses a whole range of projects interpreting literary texts or inspired by them. By analysing works of artists like Renata Pacyna-Kruszyńska, Małgorzata Haras, Janusz and Jadwiga Tryzna I try to demonstrate how authors of artists' books interpret the writers' works, using them as a basis for completely new, original and autonomous projects, and to show which direction contemporary book art may follow over the next few years.
\end{abstract}

